\title{
CERCARIA REESI N.SP., A NEW FURCOCERCOUS LARVA FROM PLYMOUTH
}

\author{
By Robert F. Hutton \\ From the Plymouth Laboratory
}

(Text-fig. I)

A new longifurcous, pharyngeate, distome cercaria has been found to develop in the marine bivalves Hiatella arctica (L.) and H. striata Fleuriau. This larva was present in 12 of 200 specimens of $H$. arctica collected from Drake's Island during the summer months (May-August) of 1952, while the same parasite was found in $\mathrm{I} 5$ of 100 specimens of the limestone borer, H. striata, dredged from Plymouth Sound during June and July of the same year.

I first learned of this larva from Dr W. J. Rees, British Museum (Natural History), who observed it several years ago in $H$. arctica (L.). However, because of other duties both then and now, he has been unable to complete a description of this species. I am indebted to him for giving me information as to its habitat and for suggesting that I give a description of this parasite; for these reasons the present species is named in his honour. Furthermore, I am grateful to Dr W. J. Rees and Dr F. G. Rees for reading and criticizing the manuscript.

Specific nomenclature for molluscs mentioned in this paper is in accordance with Winckworth (I932 and I95I).

This work was carried out at the Plymouth Laboratory of the Marine Biological Association while the author was holding a Fulbright Scholarship.

\section{METHODS}

Fully developed cercariae were obtained by isolating specimens of $H$. arctica and H. striata in glass tubes and allowing the cercariae to emerge. Sporocysts and developing cercariae were obtained by crushing specimens of these bivalves. Cercariae and sporocysts were studied alive and unstained, also fixed in sublimate and stained with Giemsa and with gold chloride. Measurements of cercariae were taken from naturally released living specimens slightly compressed between slide and cover glass.

OBSERVATIONS

Cercaria reesi n.sp. (Fig. I)

Specific diagnosis. Marine, longifurcous, pharyngeate, distome cercaria developing within ovoid to sausage-shaped sporocysts. Nonoculate; body elongate, widest slightly posterior to centre of body; cuticle covering the 


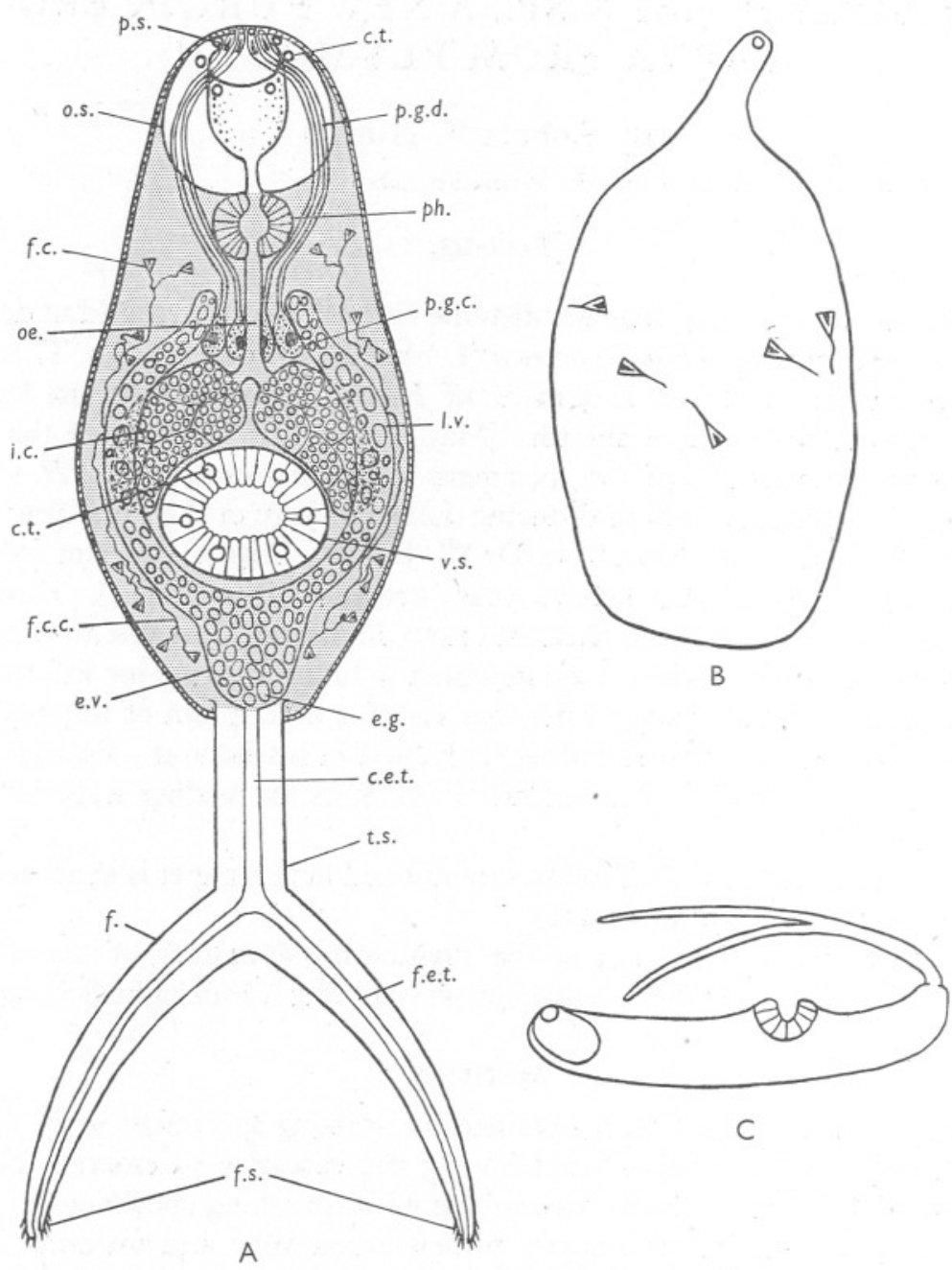

Fig. I. A, Cercaria reesi n.sp. B, sporocyst. c, swimming position of cercaria. (All figures are semi-diagrammatic.) c.e.t. caudal excretory tube; c.t. cuticular tubercle; e.g. excretory granule; e.v. excretory vesicle; $f$. furca; f.c. flame cell; f.c.c. flame cell canal; f.e.t. furcal excretory tube; f.s. furcal setae; i.c. intestinal caecum; l.v. lateral branch of excretory vesicle; oe. oesophagus; o.s. oral sucker; p.g.c. penetration gland cell; p.g.d. penetration gland duct; ph. pharynx; p.s. penetrating spine; t.s. tail stem; v.s. ventral sucker. 
body showing small dots arranged densely and regularly; this pattern seen in sections appears to be the surface view of fine striae passing obliquely through the thickness of the cuticle. Two pairs of penetration glands located dorsal and lateral to the posterior end of oesophagus, their ducts running forward to open to the exterior near the tip of the oral sucker; two pairs of protrusible penetrating spines located slightly behind the penetration-duct openings; oral sucker subterminal and ovoidal in shape with six semi-transparent tubercles present on its exterior surface; prepharynx absent; oesophagus of moderate length; intestinal caeca prominent, terminating lateral to the centre of the ventral sucker; ventral sucker elliptical, broader than long, with six semi-transparent tubercles present on its exterior surface. Excretory vesicle conspicuous, the lateral branches extending forward converging anterior to the intestinal caeca and terminating a short distance from the oesophagus; caudal excretory tube passes through the furcae to open to the exterior near their tips; the excretory formula is $2[(2+2)+(2+2)]=I 6$; tail stem attached to the body ventrally; setae on distal ends of furcae. Measurements in microns of fifty fully developed cercariae under slight pressure of cover-slip: body length I02-2I6 (av. I 59); body width 54-I00 (77); oral sucker width $30-42$ (36) pharynx width I4-22 (I8); ventral sucker width 30-42 (36); tail stem length I8-50 (34); tail stem width I2-26 (I9); furca length 30-68 (49); and distance of ventral sucker from anterior end of body 56-92 (74). The maximum diameter of the excretory granules is $6.8 \times 3.0 \mu$. Measurements in microns of fifteen living sporocysts under slight pressure of cover-slip: body length 320-800; body width I96-352.

Hosts. Hiatella arctica (L.) and H. striata Fleuriau.

Habitat. Sporocysts in digestive gland and gonad.

Locality. Drake's Island and Plymouth Sound, Plymouth, England.

Incidence of infection. $6 \%$ in $\mathrm{H}$. arctica and $15 \%$ in $\mathrm{H}$. striata.

Type material. To be deposited in British Museum.

This cercaria swims with its head in a forward direction and with its tail curved as shown in Fig. IC; this is also its normal resting position. The small dots on the cuticle of this cercaria are similar to those of Cercaria fulbrighti Hutton; in the latter larva spines develop from these areas. No significant difference was observed between measurements of cercariae from Hiatella gallicana and those from $H$. arctica.

\section{DisCUSSION}

Miller (I926) includes eight marine species in his check-list of what he considers to be all the furcocercous cercariae, excluding gasterostome cercariae, known at the time. Young (1936), reporting a fork-tailed cercaria from the Bering Sea, states: 'Thus far there have been described to my knowledge twelve marine furcocercous cercariae, at least three of which are of doubtful identity.' 
Our knowledge of marine furcocercous cercariae is still very limited. In so far as the present author is aware there are but thirty-five marine forms reported in the literature. Many of these accounts are so meagre that they are of little taxonomic value. The same species has probably been designated under more than one name.

The furcocercous cercariae, other than gasterostomes, reported from British marine waters are as follows:

\begin{tabular}{ll}
\multicolumn{1}{c}{ Parasite } & \multicolumn{1}{c}{ Author } \\
Cercaria dichotoma & Müller (according to La Valette \\
& St George, I855) \\
Cercaria sp. & Jones \& Rothschild, I932 \\
Haplocladus sp. & Rees, I947 \\
Cercaria fulbrighti & Hutton, I952
\end{tabular}

\author{
Reported by \\ Lebour, 1908, etc. \\ Jones \& Rothschild, 1932 \\ Rees, 1947 \\ Hutton, I952
}

In addition to the above list, Rothschild (I936) notes an abnormal cercaria which possesses a 'perfectly symmetrical forked tail in a species normally possessing a simple tail'.

Cercaria dichotoma Müller (according to La Valette St George, I855) is probably the larva of Tergestia laticollis (Rudolphi): most certainly it is not the same species dealt with by Pelseneer (I906) and Lebour (I908), to which both workers attributed the name Cercaria dichotoma Müller. Dawes (1946, p. 245) gives the name C. fissicauda Villot to the latter cercaria, but this does not seem likely since there are major differences between Villot's cercaria and that of Pelseneer and of Lebour. Villot reports two small teeth on the anterior border of his cercaria, yet he states that he was unable to observe a 'bulbe oesophagien'. Both Pelseneer and Lebour record the presence of a pharynx in their reports, but neither mentions the presence of any anterior teeth-like structures.

Sinitsin (I9II) described a marine fork-tailed cercaria from Abra (=Syndosmya) alba under the name Cercaria discursata. While this paper was in the proof stage, a publication was received in which Uzmann (I952) described a similar larva, C. myae, from Mya arenaria. Of the marine furcocercous larvae which have been described, Cercaria discursata and C. myae appear to be most like $C$. reesi. All three species possess two pairs of penetration glands anterior to the ventral sucker. Possession of these anterior penetration glands places these forms in the 'Strigea' group of Wesenberg-Lund (1934). However, $C$. reesi appears to differ from the other two larvae by possessing two pairs of anterior penetrating spines and by possessing cuticular tubercles on the oral and ventral suckers. Although I was unable to find any mention of cuticular tubercles, or of similar protuberances, in Sinitsin's description of C. discursata, his figure (plate III, fig. 45) shows the ventral sucker's aperture to have a fringed outline. It is possible that this shape of the ventral sucker was produced by similar structures which various authors, including myself, have termed 'cuticular tubercles'. 
At the present state of our knowledge I feel justified in separating the Hiatella parasite from Cercaria myae Uzmann and C. discursata Sinitsin under the name $C$. reesi.

\section{REFERENCES}

DAwEs, B., 1946. The Trematoda, with Special Reference to British and other European Forms. 644 pp. Cambridge University Press.

Hutton, R. F., I952. Studies on the parasites of Cardium edule L.: Cercaria fulbrighti n.sp., a Gymnophallus larva with a forked tail. Fourn. Mar. Biol. Assoc., Vol. 3I, pp. 3I7-26.

JoNeS, E. I. \& RothSCHILD, M., I932. On the sporocyst and cercaria of a marine distomid trematode from Nucula. Parasitology, Vol. 24, pp. 260-4.

La Valette St GeORge, A. DE, I855. Symbolae ad trematodum evolutionis historiam. $3^{8} \mathrm{pp}$. Berolini.

Lebour, M. V., I908. Trematodes of the Northumberland coast. No. II. Trans. Nat. Hist. Soc. Northumberland, Durham and Newcastle, N.S., Vol. 2, pp. 3-20.

Miller, H. M., I926. Comparative studies on furcocercous cercariae. Ill. Biol. Monogr., Vol. IO, II2 pp.

PelseneER, P., I906. Trématodes parasites de Mollusques marins. Bull. Sci. France Belg., T. 40, pp. I6I-86.

REES, W. J., I947. A cercaria of the genus Haplocladus from Nucula nucleus (L.). Fourn. Mar. Biol. Assoc., Vol. 26, pp. 602-4.

RotHSCHILD, M., I936. A note on the variation of certain cercariae (Trematoda). Novitates Zoologicae, Vol. 40, pp. I70-5.

Sinitsin, D. F., I9II. La génération parthénogénétique des Trématodes et sa descendance dans les Mollusques de la Mer Noire. Mém. Acad. Sci. St-Pétersb. (8), Vol. 30, pp. I-I27.

Uzmann, J. R., I952. Cercaria myae sp.nov., a fork-tailed larva from the marine bivalve, Mya arenaria. Fourn. Parasitology, Vol. 38, pp. I6I-4.

Villot, M. A., I879. Organisation et développement de quelques espèces de Trématodes endoparasites marins. Ann. Sci. nat. (Zool.), 6th Sér., T. 8, 40 pp.

WesenBerg-Lund, C., I934. Contributions to the development of the Trematoda Digenea. Part II. The biology of the freshwater cercariae in Danish freshwaters. D. Kgl. Dansk. Vidensk. Selsk. Skrifter, Naturv. Math. Afd., Raekke 9; Vol. 3, $223 \mathrm{pp}$.

WinckWORTH, R., I932. The British marine Mollusca. Fourn. Conchology, Vol. 19, pp. $2 \mathrm{II}-252$.

_ I95I. A list of the marine Mollusca of the British Isles: additions and corrections. Fourn. Conchology, Vol. 23, pp. 13I-4.

YounG, R. T., I936. A fork-tailed cercaria from Bering Sea, with a note on the marine furcocercous cercariae hitherto described. Fourn. Parasitology, Vol. 22, pp. 255-8. 